\title{
University of Western Australia
}

\author{
Vivienne Glance and Hélène Jaccomard
}

\section{A common space: translation, transcreation, and drama \\ The case of the English translation of the French play, On Arthur Schopenhauer's Sledge by Yasmina Reza}

\begin{abstract}
:
Internationally renowned French playwright and novelist Yasmina Reza's ten plays have been translated into more than 35 languages, with the exception of Dans la luge d'Arthur Schopenhauer, or On Arthur Schopenhauer's Sledge (2005). This short play is made up of eight monologues for stage but is resolutely non-dramatic. The translation of such a hybrid text from French into English is a first-time collaboration between a translator, Hélène Jaccomard, and a transcreator, Vivienne Glance.

Prior to this, Glance, the transcreator, has been working with limited-English speaking authors to co-transcreate their works into English, doing so with no knowledge of their mother tongue. In contrast, for On Arthur Schopenhauer' Sledge, Glance worked on a rough English translation, with some knowledge of the original French but no access to the author. Professional experience of acting and directing plays allowed the transcreator to ensure each character's voice sounded natural, true, and distinctive in English.
\end{abstract}

Jaccomard, the translator, translated the French text into English, a second language, when literary translators typically work into their first language. Jaccomard's command of English was often challenged by transferring a source language that is both abstract and precise, tackles philosophical ideas, and creates the characters' moods and humour.

This paper analyses how co-transcreation practice between Jaccomard and Glance operates in the space common to translation for the stage, close textual analysis, and drama performance.

\section{Biographical notes:}

Hélène Jaccomard is a Professor of French Studies and Translation Studies at the University of Western Australia. Her research interests revolve around contemporary French literature and in particular works by Yasmina Reza. She has published several articles on Reza dealing with humour and emotions in plays, politics in autobiographies, and how 'Art' has been translated into English. She has written two monographs on the dramatist's ten plays, Les Fruits de la passion: le théâtre de 
Yasmina Reza (Bern: Peter Lang, 2013), and Yasmina Reza et le bo: theatre et romans (in press).

Dr. Vivienne Glance is an Honorary Research Fellow at the University of Western Australia. She is also a practicing writer and theatre maker with works produced/published in UK, Europe, USA and Australia. She has worked for fifteen years co-transcreating the writing of non-native speakers into English, including the AWGIE-nominated The African Magician, by Afeif Ismail. She has written and presented articles on this topic and is currently under commission (ASSITEJ International) to produce videos with Ismail on this practice. Her other interests focus on the intersection of science and culture, particularly aspects of science in performance; and supporting and promoting diversity and multiculturalism in the Arts.

Keywords:

Yasmina Reza - transcreation - translation revision - collaboration - violation - theatre 
This paper analyses a collaboration between a literary translator and a translation reviser which, it could be argued, went beyond the usual translation revision compact, as they combined skills which originate from different disciplines: translation studies on one hand and creative writing on the other. Since the translation was a play, the two academics involved, Jaccomard as translator and Glance as transcreator - a translation reviser with minimal knowledge of the original language, but highly skilled in creative writing - operated in the space common to translation for the stage, close textual analysis, and drama performance. The involvement in such a process of a transcreator has not been examined by scholars to date. This paper intends to bridge the gap in scholarship.

\section{Introduction: why a translation of Yasmina Reza's On Arthur Schopenhauer's Sledge}

Yasmina Reza is the widely acclaimed author of five novels and 10 plays. All her plays bar one, Dans la luge d'Arthur Schopenhauer, or On Arthur Schopenhauer's Sledge (2005), have been translated into more than 35 languages, including English. Her bestknown dramas «Art» (1995) and God of Carnage (the basis for Roman Polanski's 2011 film, Carnage) still draw large crowds in theatres around the world and have been the highest-grossing French plays in the last twenty years. On Arthur Schopenhauer's Sledge is therefore a puzzling exception to the international dissemination of Reza's works.

Published in 2005, the play was ranked among the twenty best books of that year by an influential popular literary magazine, Lire (Anon. 2006). Yet its stage career has been brief. Apart from the occasional reading, it was performed on only two occasions in 2006, in and outside Paris, with distinguished theatre actors including Yasmina Reza. In October 2018 it was revived for a brief season in a newly refurbished theatre, La Scala Paris, and directed by the same stage director as in 2006, Frédéric Bélier-Garcia, with virtually the same cast of actors. Audiences were appreciative of 'Reza's art in capturing daily, and almost political, situations as when you have to patiently listen to ranting soliloquies' and 'how spectators' laughter goes hand in hand with deeper selfquestioning' (Laporte 2018). Reviewers had expressed regrets that the text, an 'acerbic, profound, and despairing script', lacked 'voices and motions' (Busnel \& Serri 2005). It is true the play lacks drama and action, but many plays are equally non-dramatic and static, and are still successful on stage. There is nothing in this play, even the long monologues requiring remarkable memorisation capabilities from the actors, that can't be translated on stage or into other languages.

On Arthur Schopenhauer's Sledge is a short text (10,000 words), made up of eight monologues, to be performed by a cast of four different characters addressing each other: Ariel - a retired philosophy teacher - and his wife Nadine; Serge, their mutual friend, and the couple's unnamed psychiatrist. The monologues are not interrupted by their interlocutor's replies, although on rare occasions there appears to be minimal interaction between the person talking and the person listening. Ariel seems to suffer from a nervous breakdown after becoming unconvinced that Spinoza, whom he has idolised all his life, is right in his optimistic view of life. This breakdown affects his 
wife and friend deeply, as Ariel is now a proponent of a pessimistic Schopenhauer, and is slowly going into despair, as if riding downhill on an unstoppable sledge. But, despite the title, this is not a play about philosophical ideas: even though it tackles broad questions about the meaning of life, it does so in a sardonic way, and there is no complexity in terms of meaning or even tone. The English translation needed, however, to reproduce what is at the heart of Reza's aesthetics: the unusual expressions and rare lexicon, the long-winded sentences, the hanging, unfinished phrases, and the unorthodox punctuation - an abundance of commas where you would expect semicolons or full stops. It was essential for the English version to convey the monologues' breathing pattern and rhythm. The collaboration therefore relied on a theoretical and practical understanding of translation issues, as well as the flair of a creative writer like Glance, in order for the final text to be suitable enough to be read aloud and even staged.

\section{On translation}

Translating into a second language is generally viewed as being necessarily inferior to translation into one's native language (see, for instance, Stewart 2000: 205). This view on 'translation directionality' has been recently challenged (Campbell 2013), like so many preconceived ideas in matters of translation since the so-called 'cultural turn' in translation studies (Bassnett \& Lefevere 1990). In the 1970s a more sophisticated and holistic approach to translation led to the notion of faithfulness being thoroughly deconstructed, in favour of the notion of equivalency between two texts, based on the purpose of the translation (this is called Skopos theory, see Bassnett 1990: 30sq). Nevertheless, everyone agrees that, at their most basic level, translations have to be free of lexical infelicities and morphosyntactic errors (determiners, postpositions, conjunctions), and that they respect the language register of the source text.

For a translation into a second language a thorough revision is a must, so as to ensure that the work fulfils the minimal requirements. But revision takes many guises. The Dictionary of Translation and Interpreting gives the following definition of revision: 'The process of reviewing draft translations [and] introducing corrections and improvements wherever necessary, especially in order to match the requirements of a style guide, preferred terminology or the needs of intended readers' (Laver \& Mason 2018: 116). There are many ways of doing a translation review - and a multitude of terms to cover this type of collaboration, depending on the degree of involvement with the original text. A proof-editor or sub-editor will consider the translation as a standalone text unrelated to the original text, and so will a translation reviser who is not expected to be a translator or to refer to the source text.

Below (Table 1) are a few examples drawn from the very first scene of On Arthur Schopenhauer's Sledge. The faulty, clumsy, or unnatural expressions are underlined and bolded in the first draft, translated by a non-native English speaker. Their corrections, also underlined and bolded in the final draft, are done by the Englishspeaking transcreator, who applied her intuitive sense of what is clearer, more fluent, and more idiomatic in the target language. 


\begin{tabular}{|c|c|}
\hline First draft & Final translation \\
\hline $\begin{array}{l}\text { [From the opening of the play] } \\
\text { My husband was in the habit of peeling } \\
\text { oranges by hand, with some types of } \\
\text { oranges it is defensible, when the skin is } \\
\text { thick and tear out easily, whereas when the } \\
\text { skin is thin and sticks to the wedges as in } \\
\text { most types of oranges, at any rate those } \\
\text { juicier, thus the best ones, for my part I } \\
\text { always make sure I buy such oranges, } \\
\text { attacking I } \text { with your bare hands is a } \\
\text { mistake, a gesture of pure dayliness turns } \\
\text { into an ugly and useless struggle, the } \\
\text { gesture he would have when we were } \\
\text { having breakfast would make him bang } \\
\text { the table with a kind of clockwork } \\
\text { violence, with each peel torn off his fist } \\
\text { would fall back on the wood, despite } \\
\text { himself mind you, but without his } \\
\text { realising it in any way, I mean impervious } \\
\text { to the noise and the jolt, that I would be } \\
\text { unhinged would never cross his mind [...] }\end{array}$ & $\begin{array}{l}\text { My husband was in the habit of } \\
\text { peeling oranges with his hands, with } \\
\text { some types of oranges it is defensible, } \\
\text { when the skin is thick and tears out } \\
\text { easily, whereas when the skin is thin } \\
\text { and sticks to the segments as is the } \\
\text { case for most types of oranges, at any } \\
\text { rate for those juicier ones, that is the } \\
\text { best ones, personally I always make } \\
\text { sure I buy such oranges, attacking the } \\
\text { skin with your bare hands is an } \\
\text { aberration }{ }^{3} \text {, a gesture of pure } \\
\text { dayliness turns into an ugly and } \\
\text { useless struggle, the gesture he would } \\
\text { make when we were having } \\
\text { breakfast would cause him to bang } \\
\text { the table with a kind of clockwork } \\
\text { violence, as each peel was torn off } \\
\text { his fist would fall back on the wood, } \\
\text { despite himself mind you, but without } \\
\text { him paving attention to it in any } \\
\text { way, I mean impervious to the noise } \\
\text { and the jolt, that I would be unhinged } \\
\text { would never cross his mind [...] }\end{array}$ \\
\hline but I don't care a fig $[\ldots]$ & but I couldn't care less \\
\hline my husband is in disarray $[. .]$. & my husband is distraught \\
\hline $\begin{array}{l}\text { [from the second monologue] } \\
\text { When Glen Vervorsch arrives } \\
\text { somewhere, a dreadful boredom falls } \\
\text { upon you. }\end{array}$ & $\begin{array}{l}\text { When Glen Vervorsch arrives } \\
\text { anywhere, the most deadly } \\
\text { boredom descends upon you. }\end{array}$ \\
\hline $\begin{array}{l}\text { [from the third monologue] } \\
\text { France is one of the first world exporter, } \\
\text { who knows about that Glen? }\end{array}$ & $\begin{array}{l}\text { France is one of the leading world } \\
\text { exporters, who would know that } \\
\text { Glen? }\end{array}$ \\
\hline $\begin{array}{l}\text { [from the fifth monologue] } \\
\text { Including lust getting number and } \\
\text { number as time passes, it's part of the } \\
\text { landscape too }[\ldots]\end{array}$ & $\begin{array}{l}\text { Including the dulling of desire with } \\
\text { time, it's part of the landscape ! }\end{array}$ \\
\hline$[f r$ & \\
\hline
\end{tabular}


He would never come back, I mean on time, when coming back would mean a turn-around $[\ldots]$
He would never come back, I mean on time, when coming back would mean an about-face $[\ldots]$

Table 1: Examples of linguistic errors or infelicities corrected in the final draft

Another relevant aspect of translation regards style and aesthetics. Translators have to make decisions on a matter of macro-strategy and choose between two opposing approaches: 'domestication' and 'foreignisation'. 'Domestication' aims at making the translation 'domestic', as if the text had been written directly in the target language. It is like 'bringing the writer to the reader' (Bernofsky 1997: 180), smoothing what sounds foreign, unusual, or non-idiomatic. 'Foreignisation', particularly in literary translation, is seen as a strategy for opening the target culture to new ways of saying and thinking, 'bringing the reader to the writer' (Schleiermacher qtd in Bernofsky 1997: 181), making the work more literal, and sounding closer to the original at the expense of naturalness in the final translation. For instance, the expression used by Nadine to describe what her husband has become - 'a guardian of a train depot' - might not work too well in English; or Ariel saying that 'married life [is] a confounding boat'.

When it comes to drama translation, research shows a clear tendency, particularly for the American stage (Ding 2010), towards domestication of the original text:

When translating for the theatre, a higher degree of domestication might be necessary because of the medium involved. I show that the translator not only has to take into account the spoken nature of the dialogue, but also the aural nature of its reception. (Tarantini 2016: 60)

Despite Lawrence Venuti's famous quote, that translations 'inevitably perform a work of domestication' (1998: 5), in reality most translators use a blend of both domestication and foreignisation within the same text. This is in fact the strategy adopted for the translation of On Arthur Schopenhauer's Sledge. This blend is also the strategy adopted by Reza's regular translator, British playwright Christopher Hampton (Jaccomard 2013). With Reza's reputation now well established on the world stage, a potential translator can take some risks in pushing the boundaries of what is acceptable to theatre audiences, perhaps even to the point of the target language sounding somewhat foreign.

Below (Table 2) are some examples of translation strategies which either preserved Reza's style in English at the expense of the text feeling slightly foreign or unnatural, or, on the contrary, didn't reproduce Reza's unique style, giving the text a somewhat domesticated feel. It is through the collaboration between Jaccomard and Glance that such strategies were adopted (as will be explained in the second section of this paper).

\begin{tabular}{|l|l|}
\hline Characteristics & Translation strategy \\
\hline
\end{tabular}




\begin{tabular}{|c|c|}
\hline $\begin{array}{l}\text { Adjectives used as nouns } \\
\text { nous tombons dans la faiblesse humaine, } \\
\text { I'épuisement, le triste, la maladie } \\
\text { alterner le fêlé et le } \underline{\text { normal }}\end{array}$ & $\begin{array}{l}\text { Domesticated } \\
\text { we succumb to human frailty, } \\
\text { exhaustion, } \underline{\text { sadness }} \text {, illness } \\
\text { alternate between crackpot and } \\
\text { normal }\end{array}$ \\
\hline $\begin{array}{l}\text { Unique association of words } \\
\text { un geste de pure quotidienneté } \\
\text { la charge globale de haine } \\
\text { aucune tenue dans l'être }\end{array}$ & $\begin{array}{l}\text { Foreignised } \\
\text { a gesture of pure dayliness } \\
\text { the full force of hatred } \\
\text { no hold over himself }\end{array}$ \\
\hline $\begin{array}{l}\text { Rare vocabulary } \\
\text { embarcation instead of bateau } \\
\text { caduc instead of obsolete } \\
\text { aiguière instead of vase }\end{array}$ & $\begin{array}{l}\text { Domesticated } \\
\text { boat } \\
\text { antiquated } \\
\text { vase }\end{array}$ \\
\hline $\begin{array}{l}\text { Nominal sentences } \\
\text { Aujourd'hui exaltions diverses, drogues et } \\
\text { main molle. }\end{array}$ & $\begin{array}{l}\text { Foreignised } \\
\text { Today, various intoxications, drugs } \\
\text { and a limp hand. }\end{array}$ \\
\hline $\begin{array}{l}\text { Euphemisms } \\
\text { mon mari a perdu la tête, }[\ldots] \text { son esprit a } \\
\text { lâché prise }\end{array}$ & $\begin{array}{l}\text { Foreignised } \\
\text { my husband lost his head, }[\ldots] \text { his } \\
\text { mind has given up }\end{array}$ \\
\hline
\end{tabular}

Table 2: Examples of domestication and foreignization

Irrespective of the directionality - whether translating in their native or second language - translators must possess, above and beyond lexical, morphological, and syntactic correctness, what is called textual competence, so as to convey the right feeling for a specific textual genre (Campbell 2013: 161). For On Arthur Schopenhauer's Sledge, achieving textual competency required carrying out a critical reading of the source-text - that is, first and foremost understanding its meaning, but being also aware of its aesthetics, such as its metaphors, wordplay, ambiguities, pace, and registers. In short, not only what the text means, but 'the way the text means' (Boase-Beier 2011: 74). Indeed, 'translation is a type of criticism' (Gaddis Rose 1997: 25) which pays attention to precision in lexical and syntactic choices, as they are intrinsic to a play's rhythm and impact.

Unlike the morphosyntax and linguistic accuracy exemplified in Table 1, textual competency is not black and white. In that respect, textual corrections are more debatable because one might have multiple solutions in mind and the choice between them is almost a matter of opinion. Translation scholar Anthony Pym talks of the process of translation as the ability to:

Generate more than one viable term (target text1, target text $2 \ldots$ target textn) for a source text [and] select only one target text from this series, quickly with justified 
confidence, and to propose this target text as a replacement of source text for a specific purpose and reader. (1992: 281)

Each of those 'target texts' are the result of millions of decisions and choices.

In a collaborative situation, where a translator and a translation reviser work together to meet the 'challenge to produce stylistically authentic texts' (Campbell 2013: 2), both translator and reviser will oscillate between solutions that approach equivalency, and may even change their minds as they proceed with the revision. This indeterminacy of the end-product is the reason why translations, unlike original texts, are not fixed, but rather are open texts subject to unending revisions.

In this collaboration, Glance as the reviser-transcreator not only brought her higher native-speaker's textual competence, but also happened to have experience in a different branch of translation, co-transcreation.

\section{On co-transcreation}

The meaning of the term 'transcreation' is yet to acquire a consensus. It is thought to have originated as a term loosely applied 'in contexts where literary translations were rendered mostly freely or creatively' (Morón \& Calvo 2018: 126), and, more recently, by advertising and marketing companies to talk about translation localisation:

Taking a concept in one language and completely recreating it in another language [transcreation] is normally applied to the marketing of an idea, product or service to international audiences. The language, therefore, must resonate with the intended audience. (Stibbe, 2009)

Transcreation is thus defined 'as a new service vis-à-vis other services such as translation and/or localisation' (Morón \& Calvo loc. cit.). There are signs however that transcreation has its place in translation studies beyond mere localisation of products and clients' 'creative briefs' (Ibid.: 130), with academics introducing transcreation training into their courses and supervising research theses on this aspect of translation studies.

In translation studies for performance, transcreation takes on yet another dimension. Windle, quoting Trivedi, describes transcreations 'as original works reincarnated by a "subsequent author", where "equivalence [is] based not on linguistic but cultural, aesthetic, and communicative grounds' (2011: 155).

It should be noted that Glance's practice as a transcreator has also only focused on the transcreation of fiction, song lyrics, and poetry, as well as playwriting, which are all areas of their own creative practice. Most of these collaborations have been with Sudanese-Australian poet and playwright Afeif Ismail, with whom work started in 2004.

For the purpose of On Arthur Schopenhauer's Sledge, transcreation is defined as 'an artistic reworking of a literal translation - it is a term created through conversations with writers from many cultures to distinguish it from a literal translation (Glance \& Ismail 2011: 43). Glance has had experience in such an intercultural conversation, but had previously carried this out in partnership with the original author. To this end, 
Glance uses the term co-transcreation to distinguish the unique nature of the collaboration with the translator from the work on On Arthur Schopenhauer's Sledge.

Co-transcreation works to maintain the cultural richness and specificity of the original language, and, through this process, Glance attempts to maintain the original intention and meaning of the work. There is often a tension between an accurate translation of a word or phrase, and an understanding of the cultural, linguistic, and artistic nuances in the writing. Transcreation is an attempt to honour the original atmosphere and environment intended by the writer through an active collaborative partnership, where negotiation and the consent of the original writer are essential.

This process has been used effectively to bring to the attention of an Australian public works by recent migrants whose first language is other than English. Through this process, several migrant writers have been able to continue their writing practice, and, anecdotally, this has improved their well-being and sense of social inclusion. It has also broadened the experience of the wider Australian artistic community - both those who create work and those who receive it - with different voices, styles, and ideas.

To date, the partnership with Ismail has resulted in Ismail's works being presented and published in Australia and overseas. Two plays transcreated from Arabic into English have been produced in Australia: The African Magician (Barking Gecko Theatre Company 2010) and Son of the Nile (Nexus Theatre, Murdoch University 2012). Ismail has received several awards, including a nomination for the inaugural Kit Denton Fellowship for Writers of Courage, in 2007, and he was invited to be part of Playwriting Australia's national workshop in Canberra in 2008. He was awarded the inaugural Australian National Playwrights' Conference (ANPC) Bursary, and was a recipient of an inaugural Western Australian Theatre Development Initiative (WATDI) grant for the play The Shrouds or the Dead (2009). His transcreated poetry is featured in The Fremantle Press Anthology of Western Australian Poets (Kinsella \& Ryan 2017). In 2018, Ismail was a guest speaker at the International Association of Theatre for Children and Young People (ASSITEJ) conference in Chile.

The co-transcreation partnership for On Arthur Schopenhauer's Sledge was broadly aimed at a similar objective to the work with Ismail: to build a language bridge by bringing into Australian culture a foreign voice, that of a world-famous playwright. The originality of Reza's play as described above has the potential to amuse, enlighten, and inspire English-speaking audiences. Like people who cannot read Afeif Ismail's Arabic poetry, admirers of Yasmina Reza's better-known plays are deprived of a deeper understanding of her sensitivity and range because of the language barrier - and some gaps in her translated works.

Jaccomard was new to this type of collaboration. Not only, as explained above, would she typically translate from English into a native tongue, so that her textual and linguistic competencies were not an issue, but - in her experience of commercial translation - any revision work had always been done by anonymous bilingual professionals commissioned by the client or agency. There was never any direct communication between the originator of the translation and the reviser. There was therefore no chance for justification of choices, nor a thorough process of negotiation whereby the best solution would be arrived at. As to literary translations, such as short 
stories, scholarly articles, or books ${ }^{5}$, partners - if any - would work on the first draft on their own.

At a practical level, On Arthur Schopenhauer's Sledge introduced a vastly different and more successful way of tackling a revision task. Jaccomard and Glance met between April and July 2018 to review the first draft. The many working sessions meant that Jaccomard's understanding of, and closeness to, the source text increased, as did the ability to propose new, more satisfactory re-versions. This process of negotiating the translation solutions with Glance was a transformative experience in terms of translation quality assurance.

For her part, working in a co-transcreation partnership, Glance noted both similarities and differences to transcreation practice to date, but concluded that the similarities outweighed the differences.

Some similarities are that both parties:

- Worked from a text in the source language created by the originator (the translator)

- Chose language informed through conversations regarding social and cultural norms in the source language; for instance, in the case of On Arthur Schopenhauer's Sledge, decisions had to be made regarding French proper nouns (la rue d'Ulm, la SNCF, la Comédie humaine) and brand names (le Char Leclerc, Ed), according to the assumed familiarity of an Australian audience and readership

- Decided that the final authority to determine the text lies with the translator once an issue has been discussed (discussions could be about comprehending or representing all connotations of the source text in the target text)

- Read the text aloud once a draft had been completed to ensure consistency of written tone. The working sessions gave Glance the opportunity to read the first draft aloud. Although the first few pages sounded strange at times, and led her to suggest minor modifications, little by little the transcreator started hearing the characters' voices, their breathing patterns, and warmed up to them. It is interesting to note that this familiarity seemed to be associated with more acceptance of the first draft and less calls for changes.

The differences with this particular act of co-transcreation from Glance's usual practice are:

- That the text was created in English as a translation, and not as an original text in English, so it had in effect already been mediated by the translator

- That the source text could not be changed. When realising the work on stage, it is highly probable that a stage director will alter the script, as is their prerogative

- That the text and its author must be respected by refraining from paraphrasing or making explicit the implicit subtext. Explication has been found to be one of the 'universal features' of translations, irrespective of the languages involved ${ }^{5}$, and although not necessarily a frowned-upon deviation from the 
original, it is to be resisted if it leads to a distortion of the intended effects of the source text.

The conversations that took place around cultural and social norms were informed by the translator being a French native-speaker, and understanding Reza and her intentions from critically studying her past works. While the final authority was Jaccomard's as originator of the translated text, there were interesting discussions on how characters were suggested through the text, how speech patterns were implied through punctuation, and how certain references to classical works were rendered. For instance, it had escaped Jaccomard that Serge was citing, in French, a line from Shakespeare's Macbeth (Act V, Sc. 5): 'brief candle' and 'dusty death' (l'éphémère chandelle et la mort cendreuse) (Reza 2005: 46). Glance was able to retrieve the relevant quote from the source play.

Glance's role in effect varied between that of an English editor, a dramaturge, and a performer; her knowledge of playwriting, acting, and directing (i.e. realising a text on stage) was a very useful addition. This was another new approach to previous work in this field. Although Reza, as the original creative writer of the text had an existing creative writing practice and a practical knowledge of realising a text for theatre, Jaccomard, as the text mediator, had no experience in writing for the stage.

Notwithstanding the above, this paper is focussed on the translation from the source language to the target text as a collaborative practice. By restricting the discussion to this area, the point is to show how Glance was able to bring her experiences as a dramatist and theatre practitioner to the process.

The first step in reviewing an initial translation was to work through the play text line by line and in sections. For On Arthur Schopenhauer's Sledge these sections were easily defined as the eight monologues divided up between the four characters. When each section was reviewed, the translator had an opportunity to self-revise the first draft translation. Brian Mossop claims that: 'Self-revision is an integral part of the translation production procedure; skipping it is simply unprofessional' (Mossop 2014: 18). For her part, the transcreator needed to go back to the original whenever the translation was unclear, unnatural, or difficult to say out loud. With her limited French, Glance was nevertheless able to comprehend a significant amount of the original, using the translation as a 'prop'. However, knowing some French was also at times misleading because of the many 'false friends' between English and French, like a foyer (a home) in French having nothing to do with an English foyer; or, 'en conséquence' (accordingly, as a consequence) not meaning 'in consequence'.

Translating for the page has been recognised as differing from translating for the stage. Scholars refer to the 'speakability' and 'performability' of play texts (Windle \& Malmklaer 2011; Zatlin 2005). These terms point to the unique purpose of a play text, which is the precursor to the live performance in front of an audience rather than an end in itself. In the past some play texts were published first and performed later, but this is not common practice for contemporary play text publication. However, it should be noted that, in this instance, Reza published On Arthur Schopenhauer's Sledge first, and then had it presented on stage. This could reflect the less conventionally dramatic nature of the text compared to her previous works. 
Both Jaccomard as translator and Glance as transcreator took an approach that could be described as similar to how a director and actor might read a play text in rehearsal, working through it to honour the playwright's intentions. During the working sessions, through the 'think-aloud' process used by translators to improve their practice (see Campbell 2013), they made extensive use of the thesaurus in both languages to ensure they could approximate an equivalent, or at the very least a partial, overlap of meaning. It was indispensable to revisit some banal words in English, such as 'feel' and 'believe', 'repeat' and 'reiterate', and 'distraught' and 'in disarray'. There were lengthy discussions on what a 'une main flétrie' (a 'withered hand') could be, and whether it was hanging or dangling ('[il] laisse sa main choir'); or, what 'un garcon caduc' (an 'antiquated boy') was, a peculiar expression in French. This protracted process made both collaborators realise that one knows and uses vocabulary which is not fully understood. In daily life and ordinary writing this vague, approximate comprehension is acceptable, and fuzziness and fossilisation are part and parcel of communication. However, when it comes to literature and particularly texts to be performed, one needs to pay closer attention to precision in meaning and voices.

This led to discussions on a character's state of mind and emotions, and how sentence structure, diversions of thought, repetitions, and speech patterns might all be used to imply a character's emotional state. For example, Reza runs several sentences into one another, and - at times - leaves a sentence half completed before attaching another. This indicates a person speaking their thoughts out loud, at the moment of thinking them, and thus creates authenticity and relatability in a character. This is clearly designed to produce a rhythm and even, it could be argued, to signal the playwright's intention for how the lines should be delivered. This had to be reproduced so that the character's breathing patterns would help an actor to understand a character's personality and emotional state.

\section{Conclusion}

For a translation undertaken into a second language, the experience of the authors demonstrates that a reviser is a necessity. However, the collaboration was more than a mere revision exercise for grammatical and syntactic correctness. Jaccomard was going through a process of self-revision while 'thinking aloud' the reasons for choosing some words, patterns, and expressions over others, oscillating between the best domestication or foreignisation strategies. Glance, for her part, had to pay great attention to the sounds and rhythm of the final version, using her experience as a transcreator and theatre maker to be attuned to both the pace of the original and the purpose of the translation, i.e. for the text to be performed.

Such a collaboration to produce an English translation of On Arthur Schopenhauer's Sledge also proves an important point in terms of interdisciplinary competencies for particular text types and genres. Beyond linguistic and textual competency, to be successful on the stage, translation and its revision need to draw on the skills of close textual analysis and drama performance. That is, on all the skills of the literary critic, theatre practitioner, and dramaturge. 


\section{Endnotes}

1. Our translation from the French.

2. The backwards slash '/ denotes an addition from the source text or an omission in the target text.

3. This revision is a return to the original text, when 'mistakes' didn't properly translate the French 'aberration'.

4. For instance, the translation into French of Katharine Susannah Prichard's Coonardoo (Jaccomard 1991) was done in collaboration with Jean-Pierre Delamotte, a distinguished translator of Australian literature. Delamotte revised the manuscript on his own, judging his revisions to be final.

5. See Malmkjaer 2011: 83-93.

\section{List of works cited}

Anon. 2006 'Les meilleurs livres de l'année 2005', Lire 341, at http://mamiehiou.overblog.com/2014/12/les-magazines-lire-de-2005-a-2014.html (accessed 14 October 2018)

Bassnett, Susan 2013 Translation Hoboken: Taylor and Francis

Bassnett, Susan and André Lefevere 1990 Translation History and Culture London: Pinter Publishers

Bernofsky, Susan 1997 'Schleiermacher's translation theory and varieties of foreignization' The translator 3, 175-192.

Boase-Beier, Joan 2011 'The strange paradox of stylistics and translation' in Kevin Windle and Kirsten Malmkjaer (eds) Oxford handbook of translation studies Oxford: Oxford University Press, 71-82

Busnel, François and Jérôme Serri 2005 'Entretien avec Yasmina Reza' L'express 1 September, at https://www.lexpress.fr/culture/livre/entretien-avec-yasmina-reza_810416.html (accessed 14 October 2018)

Campbell, Stuart 2013 [1998] Translation into the second language New York: Routledge

Ding, Xiaosong 2010 'Why foreignizing translation is seldom used in Anglo-American world in information age' Translation directory, at http://www.translationdirectory.com/article50.htm (accessed 24 February 2019)

Gaddis Rose, Marilyn 1997 Translation and literary criticism Manchester: St Jerome

Glance, Vivienne and Afeif Ismail 2011 'Transcreation and the productive artist' in A Arnall and U Ozolins (eds) Proceedings of the 'Synergise!' biennial national conference of the Australian Institute of Interpreters and Translators: AUSIT 2010, Cambridge Scholars Publishing, 41-46

Ismail, Afeif 2010 The African magician co-transcreators Glance, V and Ismail, A, Perth: Barking Gecko Theatre Company, directed by Jeremy Rice

Ismail, Afeif 2012 'Son of the Nile' co-transcreators Glance, V and Ismail, A, Perth: Nexus Theatre, directed by Dr David Moody

Jaccomard, Hélène 2013 'Text vs. stage: the case of Yasmina Reza's “Art” translated into British and American Englishes’ Australian journal of French studies 50 (2), 232-245

— in collaboration with Jean-Paul Delamotte 1991 Coonardoo by K. Prichard, Paris: La petite Maison [translation into French]

Kinsella, John and Tracy Ryan, 2017 The Fremantle Press Anthology of Western Australian Poetry Fremantle: Fremantle Press

Laporte, Arnaud 2018 'Dans la luge d'Arthur Schopenhauer' La Dispute, France-Culture 
https://www.franceculture.fr/emissions/la-dispute/spectacle-vivant-dans-la-luge-darthur-schopenhauersopro-le-syndrome-du-banc-de-touche-et-quasi (accessed 25 March 2019)

Laver, John and Ian Mason, I 2018 A dictionary of translation and interpreting, https://www.academia.edu/37923697/A_Dictionary_of_Translation_and_Interpreting.docx (accessed 14 October 2018)

Malmkjaer, Kirsten 2011 'Translation universals' in Kevin Windle and Kirsten Malmkjaer (eds) Oxford handbook of translation studies Oxford: Oxford University Press, 83-93

Morón, Martin and Elisa Calvo 2018 'Introducing transcreation skills in translator training contexts: a situated project-based approach' The journal of specialised translation 29, January, 126-148

Mossop, Brian 2014 Revising and editing for translators $3^{\text {rd }}$ edn Florence: Taylor and Francis

Reza, Yasmina 2005 Dans la luge d'Arthur Schopenhauer Paris: Albin Michel/LGF

Stewart, Dominic 2000 'Poor relations and black sheep in translation studies' Target 12 (2), 205-228

Stibbe, Matthew 2009 'Articulate marketing website', at https://www.articulatemarketing.com/blog/translation-vs-transcreation (accessed 14 October 2018)

Tarantini, Angela T 2016 'A psycholinguistic approach to theatre translation' The AALITRA review: a journal of literary translation 11, May, 60-77

Venuti, Lawrence 1998 The scandals of translation: towards an ethics of difference London; New York: Routledge

Windle, Kevin 2011 'The Translation of Drama' in Kevin Windle and Kirsten Malmkjaer (eds) The Oxford handbook of translation studies Oxford: Oxford University Press, 153-168

Zatlin, Phyllis 2005 Theatrical translation and film adaptation, a practitioner's view Clevedon; Buffalo; Toronto: Multilingual Matters Ltd. 